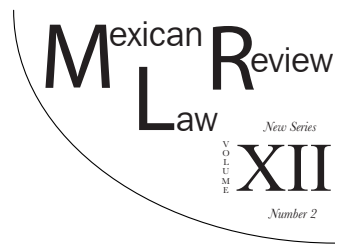

\title{
CHOOSING THE MOST FAVORABLE VENUE: FORUM SHOPPING, SHOPPING FORUMS, AND LEGAL PLURALISM IN EGUADOR
}

\section{Oswaldo Ruiz-Chiriboga*}

\begin{abstract}
This article is based on an extensive literature review and the findings obtained after three trips to Ecuador, during which interviews and informal conversations were held with members of Indigenous communities, communal leaders, national judges, prosecutors, academics and practitioners. It uses the concepts of "forum shopping" and "shopping forums," showing how these phenomena are present in both types of legal systems in Ecuador: Indigenous legal systems and the ordinary legal system. The examples provided by respondents or studied within existing legal doctrine are shared first, followed by a discussion of the opportunities and challenges the choice of forums and disputants may experience in terms of access to justice. The article also examines the ne bis in idem principle, which has been implemented to control or reduce forum shopping and shopping forums. According to this principle an individual who has faced trial in one system should not be prosecuted again in the other system. If well controlled and carefully analysed on a case-by-case basis, forum shopping and shopping forum could be beneficial to individuals and communities, fostering access to justice and the protection of human rights, without disrespecting the autonomy of communities. Conversely, if poorly controlled or badly regulated, forum shopping and shopping forum could irreparably affect justice, harm individual rights or create impunity, leaving victims or the less powerful members of communities unprotected.
\end{abstract}

KeYwords: Legal Pluralism, Forum Shopping, Indigenous Customary Law, Access to Justice

* Ph.D. Ghent University (Belgium). Postgraduate degree in Legal Argumentation, Alicante University (Spain). Postgraduate degree in Human Rights, Andean University Simón Bolívar (Ecuador). Postgraduate degree in Human Rights and Democracy, Pontifical Catholic University of Ecuador. Assistant Professor, Department of Legal Studies, Central European University (CEU), Budapest (Hungary) Email: ruizo@ceu.edu / oruizch@gmail.com.

I owe special thanks to Dr. Marc Simon Thomas (Utrecht University) for his extensive review and thoughtful comments on earlier versions of this article. 
Esta revista forma parte del acervo de la Biblioteca Jurídica Virtual del Instituto de Investigaciones Jurídicas de la UNAM

RESUMEN: Este artículo se basa en una extensa revisión de literatura y los resultados obtenidos en tres investigaciones de campo a Ecuador, durante las cuales se realizaron entrevistas y conversaciones informales con miembros de comunidades indígenas, lideres comunitarios, jueces, fiscales, académicos y litigantes. Presenta los conceptos de forum shopping y shopping forum, mostrando cómo estos fenómenos están presentes en ambos tipos de sistemas legales que tiene Ecuador: los sistemas legales indigenas y el sistema legal ordinario. Primero se comparten los ejemplos proporcionados por los entrevistados o estudiados por la doctrina, seguidos de una discusión sobre las oportunidades y desafios que la elección de foros y disputas puede tener en términos de acceso a la justicia. El artículo también examina una solución que se ha implementado para controlar o reducir el forum shopping y el shopping forum, a saber, el principio ne bis in idem, según el cual una persona que ha sido juzgada en un sistema no debe ser procesada nuevamente por el otro sistema. El artículo concluye que si se controla bien y se analiza cuidadosamente caso por caso, el forum shopping y el shopping forum podrian ser beneficiosos para los individuos y las comunidades, fomentando el acceso a la justicia y la protección de los derechos humanos, sin dejar de respetar la autonomía de las comunidades. Por el contrario, si están mal controlados o mal regulados, el forum shopping y el shopping forum podrian afectar irreparablemente a la justicia, afectar los derechos individuales o crear impunidad, dejando desprotegidas a las víctimas o a los miembros menos poderosos de las comunidades.

Palabras clave: Pluralismo Furídico, Forum Shopping, Derecho Consuetudinario Indígena, Acceso a la Justicia.

\section{Table of Contents}

I. INTRODUCTION

1. Indigenous Peoples in Ecuador and Legal Pluralism.

2. Cooperation and Coordination Between Indigenous

Legal Systems and Ecuador's Ordinary Legal System

II. Choosing the Forum and Being Chosen by the Forum

III. To Hear or Not to Hear a Case: That is the Question............... 70

IV. The $\mathcal{N E}_{\text {B }}$ IS IN IDEM Rule: a Failed ATtempt

to Limit the Possibility of Forum Shopping?

1. La Cocha 1 Murder Case: the First Attempt to Apply

the $\mathrm{Ne}$ Bis In Idem Principle....

2. La Cocha 2 Murder Case: The Constitutional Court

and Its Particular Conception of the $\mathcal{N e}$ Bis In Idem Rule

3. The Implications of the La Cocha 2 Judgment

4. Exceptions to the $\mathcal{N e}$ Bis In Idem Rule

V. Gonclusions 
Esta revista forma parte del acervo de la Biblioteca Jurídica Virtual del Instituto de Investigaciones Jurídicas de la UNAM

\section{INTRODUCTION}

\section{Indigenous Peoples in Ecuador and Legal Pluralism}

Ecuador is an ethnically rich and diverse country. There are four main ethnicities: Mestizos (Spanish descendants mixed with Indigenous populations), Afro-Ecuadorians (descendants of enslaved Africans brought by the Spanish during colonial times), Indigenous Peoples (descendants of the inhabitants of the territory before the Spanish colonization), and Montubios (rural peasants from the country's coastal zone). ${ }^{1}$ The Indigenous population is not homogenous, and is divided into 14 different nations (called nacionalidades or nationalities). ${ }^{2}$

Legal pluralism has always existed in Ecuador. ${ }^{3}$ National law and Indigenous legal systems co-existed even before independence from Spain. However, the manner in which plural legal orders have been accommodated has varied considerably across time. When the Spanish Crown colonized the Tawantinsuyo (the Inca Empire), it applied a segregationist model that kept Indigenous legal systems only for local, non-serious cases between indios, which were permitted as long as they were not contrary to the Spanish religion or laws and did not affect the colonial economic and political order-Indigenous legal systems were subordinate within legal pluralism. ${ }^{4}$ In 1830 the

1 Instituto Nacional de Estadísticas y Censos [National Institute of Statistics and Census], Censo de Poblacióny Vivienda 2001 [2001 Population and Housing Census], available at http://wrwre. inec.gob.ec/estadisticas/?option=com_contentEview $=$ articleEid $=232$ EItemid $=176$.

2 Indigenous peoples classify themselves in nations (nacionalidades), peoples (pueblos) and communities (comunidades). There are 14 Indigenous nations, each one with its own culture, language, dress, organization, etc. The Kichwa nation, the largest in the country $47.5 \%$ of the Indigenous population), is divided into 14 pueblos. The Manta-Huancavilca-Puná nation is divided into three pueblos. These pueblos are formed by communities. A community is a grouping of families. The rest of the nations are only formed by communities (not pueblos). See, Ministerio Coordinador de Patrimonio [Ministry Coordinator of Heritage] and UNICEF (2008), Nacionalidades y pueblos indígenas, y políticas interculturales en Ecuador [Nationalities and Indigenous peoples, and intercultural policies in Ecuador], available at http://www.uniceforg/ecuador/policy_ rights_23964.htm.

3 Franz von Benda-Beckmann, Who's Afraid of Legal Pluralism?, 47 JoURNAL OF LEGAL PLURALISM AND UNOFFICIAL LAW 37, 37 (2002) (This article defines legal pluralism as the simultaneous existence of two or more legal orders pertaining to more or less the same set of activities within "one socio-political space, based on different sources of ultimate validity and maintained by forms of organization other than the state"). See also: Franz von Benda-Beckmann and Keebet von Benda-Beckmann, The Dynamics of Change and Continuity in Plural Legal Orders, 53-54 JoURNAL of Legal Pluralism and UNofficial Law 1, 14 (2006); Donna Lee Van Cott, A Political Analysis of Legal Pluralism in Bolivia and Colombia, 32 JoURNAL of LATIN AMERICAN STUDIES 207209 (2000).

4 Marc Simon Thomas, The Challenge of Legal Pluralism. Local Dispute Settlement and the Indian-State Relationship in Ecuador 49-50 (Routledge 2017) (This text describes how that the Spanish colony was divided into two "republics": the Spanish Republic 
Esta revista forma parte del acervo de la Biblioteca Jurídica Virtual del Instituto de Investigaciones Jurídicas de la UNAM

independent Republic of Ecuador replaced the segregationist model with an assimilationist one, with the purpose of creating one republic under one normative system, with one official language and one official religion. ${ }^{5}$ Indigenous legal systems became illegal. Yet, Indigenous peoples continued to use and apply their laws. From the 1920s onward, an integrationist model came into play; certain collective rights and Indigenous cultural particularities were legally protected, but the monist legal order remained in force.

The exclusion of Indigenous peoples' legal systems is an example of the marginalization they have suffered over time. In response, Indigenous peoples organised a peasant resistance, which later became an Indigenous struggle that created one of the strongest social movements in the region. ${ }^{6}$ Ecuador's biggest Indigenous organization was founded in 1986. The Confederación de Nacionalidades Indígenas del Ecuador (Confederation of Indigenous Nationalities of Ecuador, CONAIE) is a national organization which has contributed to a relative improvement in the social position of the Indigenous population. ${ }^{7}$ In collaboration with its own political party, Pachakutik, CONAIE members mounted a series of actions, including protests, strikes and participation in elections. ${ }^{8}$

The so-called "Indigenous uprising" of 1990 and the Indigenous movement's continuous pressure during that decade, whether in the streets or through Pachakutik in politics, ${ }^{9}$ contributed to the adoption of a new Consti-

(República de españoles) and the Indian Republic (República de indios), each republic had different laws. Rural Indigenous peoples could resort to Spanish law, but they could also use customary law to settle internal disputes).

5 Id at 50-52 (stating that the division into two different "republics" was abolished and the process of building a single unified nation started).

6 Id at 52-54.

7 For a description of CONAIE's history and achievements, see DEBORAH J. YASHAR, Contesting Citizenship in Latin America: The Rise of Indigenous Movements and the PostLiberal Challenge (Cambridge University Press 2005); Leon Zamosc, The Indian Movement in Ecuador: From Politics of Influence to Politics of Power, in The Struggle for Indigenous Rights in Latin America (Nancy Grey Postero \& Leon Zamosc eds., Sussex Academy Press 2004).

8 Marc Becker, Indians and Leftist in the Making of Ecuador's Modern Indigenous Movements (Duke University Press 2008).

9 Ileana Almeida et al. Indios. Una REFLEXIÓn SObRe El LEVANTAMiENTO INDíGENA de 1990 [Indians. A Reflection on the Indigenous Uprising of 1990] (Abya-Yala 1991); Pablo Ospina, Reflexiones sobre el transformismo: movilización indígena y régimen político en el Ecuador (1990-1998) [Reflections on Transformism: Indigenous Mobilization and Political Regime in Ecuador (19901998)], in Los movimientos sociales en las democracias andinas [The Social Movements in the Andean Democracies] 125 (Julie Massal \& Marcelo Bonilla eds., FLACSO 2000); Fernando Guerrero \& Pablo Ospina, El poder de la comunidad. Ajuste estructural y movimiento indígena en los Andes ecuatorianos [The Community's Power. Structural Adjustment and Indigenous Movement in the Ecuadorian Andes] (CLACSO 2003); Pablo Dávalos, Movimiento indígena, democracia, Estado y plurinacionalidad en Ecuador [The Indigenous Movement, Democracy, State and Plurinationality in Ecuador], 10(1) REVISTA VENEzolaNa DE ECoNomía $r$ 
tution in $1998 .{ }^{10}$ Among the changes brought by the 1998 Constitution ${ }^{11}$ was the recognition of Indigenous legal systems as a way to solve internal conflicts. This was the first time in Ecuadorian history that a legal system other than the State-controlled one was formally accepted as valid within the territory. The monistic legal culture began to yield to a pluralistic legal culture. ${ }^{12}$

Customary Indigenous law is an integral part of the culture and a key element of ethnic identity, to the point that some authors affirm that an Indigenous community without its legal system has lost an important part of its identity. ${ }^{13}$ Indigenous legal systems embrace a variety of norms, procedures and authorities that regulate the social life of their communities, and that permit them to resolve their conflicts in accordance with their own worldviews, values, necessities and interests. ${ }^{14}$

The 1998 Constitution did not last long. It was seen as neoliberal and tailor-made to represent the interests of the county's elite. Rafael Correa Delgado started his presidential campaign in 2006 by advocating for a new, more democratic and socialist constitution. ${ }^{15}$ Correa won the elections and imme-

CIENCIAS SocIALES 175 (2004); Ana María Larrea Maldonado, El movimiento indígena ecuatoriano: participación y resistencia [The Ecuadorian Indigenous Movement: Participation and Resistance], 13 OSAL 67 (2004); José SÁnchez Parga, El movimiento indígena Ecuatoriano. La larga RUTA DE LA COMUNIDAD AL PARTIDO [The Ecuadorian Indigenous Movement. The Long Route from the Community to the Party] (Centro Andino de Acción Popular 2010).

10 Office of the High Commissioner for Human Rights (OHCHR), Viviendo la Justicia. Pluralismo jurídico y Justicia indígena en el Ecuador [Living Justice. Legal Pluralism and Indigenous Justice in Ecuador] (OHCHR 2012).

11 The most important changes brought by the 1998 Constitution were: (a) the acknowledgement of diversity in unity, which intended to consolidate and reinforce the unity of the Ecuadorian nation, while recognizing at the same time the diversity of its regions, peoples, ethnicities and cultures; (b) the emergence of a new State which should be multi-cultural and multi-ethnic; (c) the official recognition of Indigenous languages used in Indigenous territories; and (d) a number of collective rights for Indigenous peoples concerning identity, social organization, consultation, levels of authority, education, etc. See, Atik Kurikamak Yupanki, Fusticia indígena en el Ecuador: visión de un saraguro [Indigenous Justice in Ecuador: A Vision of a Saraguro], in JustiCIA INTERCULTURAL EN LOS PAÍSES ANDINOS: CONTRIBUCIONES PARA SU ESTUDIO [Intercultural Justice in the Andean Countries: Contributions for Its Study] 86 (Aníbal Gálvez Rivas \& Cecilia Serpa Arana eds., Red Andina de Justicia de Paz y Comunitaria 2013).

12 Solveig Hueber, Cambios en la administración de justicia indígena en Ecuador después de la Reforma Constitucional de 1998 [Changes in the Administration of Indigenous Justice in Ecuador after the Constitutional Reform of 1998], 83 ECUADOR DEBATE 109 (2011).

13 Rodolfo Stavenhagen, Derecho indígena y derechos humanos en América Latina [Indigenous Law and Human Rights in Latin America] (Instituto Interamericano de Derechos Humanos 1988); María Teresa Sierra, Autonomía y pluralismo jurídico: el debate mexicano [Autonomy and Legal Pluralism: The Mexican Debate”, LVIII AMÉRICA INDÍGENA 21 (1998).

14 Raquel Yrigoyen, El debate sobre el reconocimiento constitucional del derecho indígena en Guatemala [The Debate on the Constitutional Recognition of Indigenous Law in Guatemala], LVIII AMÉRICA INDÍGENA 81 (1998).

15 Alberto Acosta et al. Entre el quiebre y la realidad. Constitución de 2008 [Between Rupture and Reality. Constitution of 2008] (Abya-Yala 2008). 
diately called for a referendum, asking Ecuadorians if they agreed to change the Constitution. The electorate answered yes and by the end of October 2008, Ecuador had a new Constitution. ${ }^{16}$

The Constitution of $2008^{17}$ declares Ecuador an "intercultural and plurinational state". ${ }^{18}$ The Constitution maintains, strengthens and incorporates new and special rights for Indigenous peoples and Afro-descendants; ${ }^{19}$ and awards Indigenous peoples, Afro-Ecuadorians and Montubios the right to establish territorial constituencies to preserve their cultures. ${ }^{20}$ The most important provisions for the purpose of this article are the Articles $57(10)^{21}$ and 171 of the Constitution, ${ }^{22}$ which provide legal plurality, recognizing judicial and legislative functions to the authorities of Indigenous peoples, based on ancestral traditions and customary law within their territory.

With the recognition of the Indigenous authorities' powers of adjudication, the Ecuadorian state advanced towards "formal legal pluralism,"23 which moved from the sphere of a struggle by members of excluded cultures to become a state policy. ${ }^{24}$ The constitutional recognition of Indigenous legal

16 For an analysis of the 2008 constitutional change, see: Rafael Quintero López, LA Constitución del 2008. Un anÁlisis Político [The Constitution of 2008. A Political Analysis] (Abya Yala 2008); Adrian López \& Paula Cubillos Celis, Análisis del referéndum constitucional 2008 en Ecuador [Analysis of the 2008 Constitutional Referendum in Ecuador], 33 Ícovos 13 (2009).

17 See, Constitution (Ecuador), R.O. No. 449, 20 October 2008.

18 Id Art. 1.

19 Id Art. 57.

20 Id Art. 60

${ }^{21} I d$, Art. 57(10), which reads: "The State recognizes and guarantees to the Indigenous communes, communities, peoples and nationalities, in accordance with the Constitution and the treaties, covenants, declarations and other international instruments on human rights, the following collective rights: [...] (10) To create, develop, implement and practice their own customary law, which may not violate constitutional rights, in particular women, children and adolescents' rights".

22 Id Art. 171, which reads: "The authorities of Indigenous communities and nationalities exercise judicial functions, based on their ancestral traditions and their own systems of law, within their territory, with a guarantee of participation of and decision-making by women. The authorities shall apply rules and procedures for resolving internal conflicts, and not contrary to the Constitution and human rights recognized in international instruments. The State shall ensure that Indigenous jurisdiction decisions are respected by public institutions and authorities. Such decisions will be subject to constitutional review. The law shall establish mechanisms of coordination and cooperation between Indigenous jurisdiction and ordinary jurisdiction."

23 André Hoekema, Hacia un pluralismo jurídico formal de tipo igualitario [Towards a Formal Legal Pluralism of an Egalitarian Nature], LVIII AMÉRICA INDÍGENA 263 (1998).

24 Catherine Walsh, Interculturalidad, reformas constitucionales y pluralismo jurídico [Interculturality, Constitutional Reforms and Legal Pluralism], in Justicia indígena. Aportes Para un DEBate [Indigenous Justice. Contributions for a Debate] 23 (Judith Salgado ed., Universidad Andina Simón Bolívar 2002). 
systems has had multiple impacts. First, it gives Indigenous laws the same value and binding power as national laws. ${ }^{25}$ Second, public institutions, particularly judges and courts, must modify their legally monistic practices, ${ }^{26}$ by interpreting and applying the Constitution and secondary laws in an intercultural way. ${ }^{27}$ Third, the Parliament lost its legislative monopoly. Today, Indigenous authorities share the power to create, modify and abolish the laws that regulate their internal affairs. ${ }^{28}$ Finally, Indigenous legal systems were put on equal footing with national law, which means inter alia that Indigenous authorities have the same legal and judicial powers as national authorities. ${ }^{29}$

25 Luis Fernando Ávila Linzán, Los caminos de la justicia intercultural [The Paths of Intercultural Justice], in Derechos ancestrales: Justicia en contextos pluRinacionales [Ancestral Rights: Justice in Plurinational Contexts] 145, 178 (Carlos Espinosa \& Danilo Caicedo eds., Ministerio de Justicia y Derechos Humanos 2009).

26 Gina Chávez Vallejo, El derecho propio: ;Destapando la caja de Pandora! [Own Law: Uncovering the Pandora's Box!], in Desafíos constitucionales: La Constitución eguatoriana deL 2008 en perspectiva [Constitutional Challenges: The Ecuadorian Constitution of 2008 in Perspective] 67, 82 (Ramiro Ávila Santamaría, Agustín Grijalva Jiménez \& Rubén Martínez Dalmau eds., Ministerio de Justicia y Derechos Humanos 2008).

27 Agustín Grijalva, El Estado plurinacional e intercultural en la Constitución ecuatoriana de 2008 [The Pluri-national and Intercultural State in the 2008 Ecuadorian Constitution], in Derechos ANCestrales: Justicia en CONTEXTOS PluRinacionales [Ancestral Rights: Justice in Plurinational Contexts] 389, 394 (Carlos Espinosa \& Danilo Caicedo eds., Ministerio de Justicia y Derechos Humanos 2009). See also, Código Orgánico de la Función fudicial (Organic Code of the Judiciary), R.O. Sup. No. 544, 9 March 2009, Article 344, which requires ordinary judges, prosecutors, public defenders, the police, and other public servants to apply the following principles: (1) diversity: the law, customs and traditional practices of Indigenous communities and peoples must be taken into account, with the aim of guaranteeing the maximum recognition and the full realisation of cultural diversity; (2) equality: to take measures to understand the rules, procedures and legal consequences of the proceedings in which Indigenous peoples are involved; (3) ne bis in idem: the decisions of Indigenous authorities shall not be assessed or reviewed by ordinary judges or administrative authorities, without prejudice to constitutional review; (4) pro Indigenous jurisdiction: in case of doubt between ordinary jurisdiction and Indigenous jurisdiction, the latter shall be used; and, (5) intercultural interpretation: when Indigenous individuals or groups appear before ordinary judges or administrative authorities, the latter shall take into consideration relevant Indigenous customary law when interpreting and applying the Constitution and international human rights instruments

28 Oswaldo Ruiz-Chiriboga, La justicia indígena en el Ecuador: pautas para una compatibilización con el derecho estatal [ndigenous Justice in Ecuador: Guidelines for Compatibility with State Law], in Aportes ANDinos SObRe DEREChOS humanos. Investigaciones MONOGRÁficas [Andean Contributions on Human Rights. Monographic Researches] 53, 69 (César Gamboa et al, Universidad Andina Simón Bolívar 2005).

29 Agustín Grijalva \& José Luis Exeni Rodríguez, Coordinación entre justicIas, ese desafio [Coordination between Justices, that Challenge] in Justicia INDíGENA, PLURINACIONALIDAD E INTERculturalidad en Ecuador [Indigenous Justice, Plurinationality and Interculturality in Ecuador] 581, 592 (Boaventura de Sousa Santos \& Agustín Grijalva eds., Abya Yala 2012). See also, Esther Sánchez Botero \& Isabel C. Jaramillo, La jurisdicción especial indígena [The Special Indigenous Jurisdiction], in Derechos ancestrales: Justicia en contextos Plurinacionales 
That said, the actions of Indigenous authorities must be compatible with the Constitution and with international human rights law. This is clearly stated in the same constitutional provisions that grant legislative and judicial powers to Indigenous groups. Article 57(10) state "customary law [...] may not violate constitutional rights, in particular women, children and adolescents' rights". Article 171 stipulates that Indigenous authorities may not act contrary to the Constitution or human rights as recognized in international instruments.

Similarly, ILO Convention 169 (1989) and the UN Declaration on the Rights of the Indigenous Peoples (2007) seem to suggest that the international community is more lenient and willing to accept and enforce Indigenous legal systems. Nevertheless, these international instruments demand that Indigenous systems respect recognised human rights standards. The scope of human rights and states' responsibilities to their citizens, however, is not always completely clear. Sometimes these standards cannot be interpreted and applied in the same way they are interpreted or applied in regular proceedings in western states. ${ }^{30}$

\section{Cooperation and Coordination Between Indigenous Legal Systems and Ecuador's Ordinary Legal System}

In Ecuador there is no single Indigenous legal system, rather there are many. As was noted by various respondents, there could be as many legal systems as Indigenous communities. I was able to see by myself that there are variations in the proceedings even between two communities that belong to the same group, speak the same language, live a few kilometres apart, and have continuous contact with each other. ${ }^{31}$

[Ancestral Rights: Justice in Plurinational Contexts] 125, 160-171 (Carlos Espinosa \& Danilo Caicedo eds., Ministerio de Justicia y Derechos Humanos 2009). This text explains that, since ordinary and Indigenous authorities are on equal footing, they both have the notio, iudicium, and imperium powers. The notio is defined as the power to hear matters that are under the jurisdiction of each judge, according to the national or Indigenous laws. It includes the power to summon the parties, collect evidence, make notifications, etc. The iudicium is the ability to resolve the matter under consideration. The imperium is the power to enforce the law and to implement judicial decisions. It presupposes the power to enact penalties and sanctions for breaches of the law).

30 Rosembert Ariza Santamaría, Coordinación entre sistemas jurídicos y adminisTRACiÓN DE JUSTICIA INDíGENA EN Colombia [Coordination between Legal Systems and Indigenous Justice Administration in Colombia] (Inter-American Institute of Human Rights 2010); Oswaldo Ruiz-Chiriboga, You Have no Right to Remain Silent: Self-Incrimination in Ecuador's Indigenous Legal Systems, 65 The American Fournal of Comparative LaW 659 (2017).

31 Boaventura de Sousa Santos, Cuando los excluidos tienen Derecho: justicia indígena, plurinacionalidad e interculturalidad [When the Excluded Have Law: Indigenous Justice, Plurinationality and Interculturality], in Justicia INDÍGENa, PLURINACIONALIDAD E INTERGUlturalidAD EN EGUADOR [Indigenous Justice, Plurinationality and Interculturality in Ecuador] 13 (Boaventura de Sousa 
Being that there are multiple forums in which legal battles can play out it is not surprising to see clashes of jurisdictions between Indigenous legal systems (called justicia indígena, which translates as "Indigenous justice") and the state's justice system (called justicia ordinaria, "ordinary justice") or among different Indigenous legal systems. When there is a conflict between two or more Indigenous forums, a solution is sought through negotiation, and the results vary. Indigenous adjudicators ${ }^{32}$ from different communities may decide that one of them should hear the case, that the adjudicators of all involved communities should decide the case together, or that the case should be referred to the authorities of the Pueblo, the authorities of the Indigenous nation, or even to the ordinary justice system. ${ }^{33}$

Conflicts between Indigenous justice and ordinary justice are another matter. Negotiation plays no role and, according to the Constitution, the Parlia-

Santos \& Agustín Grijalva eds., Abya Yala 2012) (explaining the main differences between Indigenous legal systems); Raúl Llasag Fernández, Avances, limites y retos de la administración de justicia indigena en el Ecuador año 2010: El Caso La Cocha [Advances, Limits and Challenges of the Administration of Indigenous Justice in Ecuador 2010: The Gase La Cocha] in Develando EL Desencanto. Informe sobre Derechos humanos Eguador 2010 [Unveiling the Disenchantment. Human Rights Report Ecuador 2010] 94 (Universidad Andina Simón Bolívar 2010) (arguing that different groups create different norms in different ways).

32 The broad term "adjudicator" is used in Ecuador to cover the different types of investigative and deciding authorities that Indigenous peoples have. For instance, if there is a conflict within the family, the deciding authorities will be the parents, grandparents or godparents. If the conflict is not solved or if it affects multiple families, then the Cabildo (a council of leaders) is involved. Serious cases or conflicts not solved by lower authorities are referred to the Asamblea (Assembly), which is the gathering of every single one of the community's members, children included. The Asamblea is the highest authority in which everyone is able to participate, whether supporting one of the parties, confirming or challenging the versions of the witnesses, questioning the participants, giving input to solve the conflict, or determining the proper punishments. For a description of Indigenous proceedings in Ecuador's highlands, see: JAIME Vintimilla, Derecho indígena, conflicto y Justicia comunitaria en comunidades Kichwas del Ecuador [Indigenous Law, Conflict and Community Justice in Kichwa Communities of Ecuador] (Instituto de Defensa Legal 2007); Fernando García, Experiencias de dos comunidades de las provincias de Chimborazo y Tungurahua [Experiences of Two Communities in the Provinces of Chimborazo and Tungurahua], in Normas, PRocedimientos y SANCIONES DE LA JUSTICiA indígena en Colombia y Eguador [Rules, Procedures and Sanctions of Indigenous Justice in Colombia and Ecuador] 59 (Eddie Cóndor ed., Comisión Andina de Juristas 2012); Fernando García, No se aloquen, no vayan a carrera de caballo, vayan a carrera de burro: comunidades Chimborazo y Chibuleo [Do Not Go Crazy, Do Not Go at Horse Step, Go at Donkey Step: Chimborazo and Chibuleo Communities], in Justicia INDígena, PLuRinacionalidad E INTERGulturalidad EN EGUADOR [ndigenous Justice, Plurinationality and Interculturality in Ecuador] 501 (Boaventura de Sousa Santos \& Agustín Grijalva eds., Abya Yala 2012); Judith Salgado (ed.), Justicia INDíGENA. APORTES PARA Un DEBATE (Universidad Andina Simón Bolívar 2002).

33 María Mercedes Lema, Acceso a la justicia y derechos humanos en Ecuador [Access to Justice and Human Rights in Ecuador] (Instituto Interamericano de Derechos Humanos 2009). This text explains how certain communities agree among themselves on how they are going to resolve a conflict when the parties in the case belong to different communities. 
ment should have passed a law on the cooperation and coordination among both types of justice systems. No such law has been adopted yet, despite the different drafts that have been submitted over the past decade. ${ }^{34}$

This article will present the different scenarios Ecuador's legal pluralism offers to citizens and forums towards the settlement of disputes. It is the result of documentary research and fieldwork conducted in the country in 2013, 2014 and 2015 by means of interviews, informal conversations, and archival research in seven cities (Quito, Guayaquil, Cuenca, Saraguro, Guaranda, Loja and Riobamba) and four Indigenous communities: Saraguro and Tucarta (Province of Azuay), San Lucas (Province of Loja), and Pambabuela (Province of Bolívar). All of these communities belong to the Kichwa Nation. ${ }^{35}$ The interviews were with judges, prosecutors, public servants, academics, activists and Indigenous leaders. In total, 33 interviews were conducted. ${ }^{36}$

34 On the different drafts submitted to the Parliament see: Salgado, supra n. 32; Simon Thomas, supra n. 4; Lieselotte Viaene \& Guillermo Fernández-Maldonado, La brecha entre el compromiso y el cumplimiento con los derechos de los pueblos indígenas. Reflexiones sobre los avances y retrocesos en materia de justicia indígena en Ecuador [The Gap between Commitment and Compliance with the Rights of Indigenous Peoples. Reflections on the Advances and Setbacks in the Area of Indigenous Justice in Ecuador], in DesAFíos DEL PLURALISMO INTEGRATIVO Y JURÍDICO [Challenges of Integrative and Legal Pluralism] 63 (Anna Margherita Russo, Oswaldo Ruiz-Chiriboga \& Guerino D'Ignazio eds. Special Edition 9 (1) INTER-AMERICAN AND EUROPEAN HUMAN RIGHTS JOURNAL 2016).

35 The communities were selected based on the following criteria: (a) high level of organization, (b) frequent administration of justice or close contact with state officials (e.g. judges, prosecutors, police officers); (c) location in provinces with high percentages of Indigenous population; and (d) openness to receive outsiders and give interviews. I was not allowed by the Indigenous leaders to do direct observation, and therefore I did not witness any interrogation, trial or sentencing hearings.

36 The respondents were selected as follows: (a) academics and activists were chosen beforehand, based on the researcher's perception of their knowledge of relevant topics and because of their published papers or public declarations; (b) Indigenous leaders were selected in the field and after they were introduced to the researcher by a third person; and (c) public servants were selected because of their functions and contact with Indigenous communities, either because they directly serve them (e.g. police officers), have jurisdiction over the same territory as the interviewed Indigenous adjudicators (e.g. judges and prosecutors), or have competence over judicial affairs in the selected provinces (e.g. public servants working for the Judicial Council). All were semi-structured interviews. At the beginning of each interview, all the participants were instructed about the objective and methodology of the study and they received information on the researcher. The respondents were also informed of their right to stop collaboration at any point. The researcher requested their permission to audiotape the interview. Based on this information, all participants gave their informed consent and agreed to the interview and its recording. At the end of each interview, participants were offered the contact details of the researcher in case they needed additional information. The researcher also offered anonymity to the respondents, but the majority of the respondents wanted the researcher to name them or gave their authorization to do so. Only in a few cases interviewees specifically chose anonymity, and therefore remain anonymous. Additionally, informal conversations (unrecorded) were held with a wide variety of individuals in the different cities and communities the researcher 
The remainder of this article will be structured as follows: section II presents the concepts of "forum shopping" and "shopping forums", showing how these phenomena are present in Ecuador. Examples given by the respondents or through existing legal doctrine are given, and the opportunities and challenges regarding the choice of forums and disputants may have in terms of access to justice are discussed. Section III shows that Ecuador's Constitution provides that the administration of Indigenous justice is a collective right Indigenous nations have, but this study maintains that such a collective right does not imply absolute discretion by Indigenous adjudicators. Their discretion is limited by the members' individual rights to access to justice. Exercising discretion means having a choice, and therefore every time the adjudicators decide to accept a complaint they are "shopping" the dispute. Section IV examines a strategy that has been established to control or reduce forum shopping and shopping forums, namely through the ne bis in idem principle, according to which an individual who has faced trial in one system should not be tried again under the other system. Finally, Section V includes concluding remarks, stating that if well controlled and carefully analysed on a case-by-case basis, forum shopping and shopping forums could, in fact, be beneficial to individuals and communities, fostering access to justice and the protection of human rights, without disrespecting the communities' autonomy. Conversely, if poorly controlled or badly regulated, forum shopping and shopping forums could irreparably affect justice, harm individual rights or create impunity, leaving victims or less powerful members of the communities unprotected.

\section{Choosing the Forum and Being Chosen by the Forum}

Forum shopping has been defined as "the act of seeking the most advantageous venue in which to try a case". ${ }^{37}$ It occurs when disputants "have a choice between different institutions and they base their choice on what they hope the outcome of the dispute will be, however vague or ill-founded their expectations may be". 38 Traditionally, forum shopping was understood to take place horizontally or vertically. ${ }^{39}$ A party forum shops horizontally when they choose the best venue for their interests from among multiple same-level courts (e.g. choosing among courts belonging to the same federal state or among first instance criminal courts of the same locality). Forum shopping

visited. The researcher talked with members of Indigenous communities, police officers, public registers, judicial assistants, lawyers, court clerks, and other public servants.

37 Mary Garvey Algero, In Defense of Forum Shopping: A Realistic Look at Selecting a Venue, 78 NEBRASKA LAW REVIEW 79 (1999).

38 Keebet von Benda Beckmann, Forum Shopping and Shopping Forums: Dispute Processing in a Minangkabau Village in West Sumatra, 19 JourNaL of LEGAL PLURALISM 117 (1981).

39 Garvey Algero, supra n. 37 at 80. 
can also take place vertically when a party is trying to move between courts of different levels (e.g. moving from a state court to a federal court). Modern conceptions of forum shopping not only include the strategic choice of adjudicatory forum but also attempts to litigate identical or related claims in multiple forums at the same time (simultaneous forum shopping) or presenting successive related petitions (sequential forum shopping). ${ }^{40}$

The idea behind all these types of forum shopping is the same: the party that shops is seeking an advantage or wants to begin the proceedings with the odds in their favor. The choice of forum would then be a "rational choice" where disputants act strategically in order to maximize their interests and benefits. ${ }^{41}$ However, empirical research in Ecuador shows that forum shopping is not always a strategic and rational action. The decision-making process is far more complex, involving reasons related to power and politics, or lack of access to formal justice due to factors including time, money or language. As Simon Thomas put it, "Legal anthropological research shows that forum-shopping practices are embedded in social, cultural, and political contexts and therefore encompass a broader scope than legal scholars' rational choice assumptions". ${ }^{42}$

The options for choosing the venues in which to allocate a case can vary for number of reasons. ${ }^{43}$ Individuals may have a limited knowledge of national law, and therefore it is not really an option for them. Similarly, individuals may understand national law very well, but it is not accessible, and therefore they are forced to resort to Indigenous law. Individuals with good knowledge of national law and who have the means (economic, linguistic, cultural, etc) to access it have more options to choose from. ${ }^{44}$

The parties are not the only ones that shop forums, as the opposite could also occur: forums search for disputes to advance their own interests. This is known as shopping forums. In studying a legally pluralistic society, Von Benda-Beckmann noted:

40 Laurence R. Helfer, Forum Shopping for Human Rights, 148(2) UNIVERSITY of PENNSTLVANIA LAW REVIEW 285, 290 (1999).

41 Luis Fernando Ávila Linzán, Disputas de poder y justicia: San Lucas (Saraguro) [Disputes of Power and Justice: San Lucas (Saraguro)], in Justicia INDÍGENA, PLURINACIONALIDAD E INTERCULTURALIDAD EN ECUADOR [Indigenous Justice, Plurinationality and Interculturality in Ecuador] 373, 412-413 (Boaventura de Sousa Santos \& Agustín Grijalva eds., Abya Yala 2012).

42 Marc Simon Thomas, Forum Shopping: The Daily Practice of Legal Pluralism in Ecuador, in Andeans and Their Use of Cultural Resources: Space, Gender, Rights \& Identity 85, 94 (Arij Ouweneel ed., CEDLA 2013).

43 This is why some authors consider forum shopping not to be a useful concept to describe Ecuador's legal reality (Simon Thomas, supra n. 42).

44 On the topic of knowledge of national law see, Susan Berk-Seligson, Fudicial Systems in Contact: Access to Fustice and the Right to Interpreting/Translating Services among the Quichua of Ecuador, 10 International Journal of Research and Practice in Interpreting 9, 12 (2008); García, Experiences of Two Communities, supra n. 32 at 86-96; Simon Thomas, supra n. 42 at 96. 
Not only do parties shop, but the forums involved use disputes for their own, mainly local political ends. These institutions and their individual functionaries usually have interests different from those of the parties, and they use the processing of disputes to pursue these interests. So besides forumshopping disputants, there are also 'shopping forums' engaged in trying to acquire and manipulate disputes from which they expect to gain political advantage, or to fend off disputes which they fear will threaten their interests. They shop for disputes as disputants shop for forums. Indeed, manipulating with disputes seems to be a favorite pastime of many functionaries. ${ }^{45}$

In talking about Ecuador, Ávila Linzán shows that in certain communities their members access either ordinary or Indigenous courts. Generally, when ordinary justice delays a ruling on a case or does not rule in the benefit of a community member, community members may resort to Indigenous justice (sequential forum shopping). ${ }^{46}$ Indigenous adjudicators can also be political, administrative or religious leaders in their communities, and can seek to legitimize their management policy by incentivising forum shopping, demonstrating how they can solve a conflict that took too much time or was not solved properly, in their view, in the ordinary justice system.

Grijalva claims Indigenous justice and ordinary justice as appear to operate in a subsidiary and parallel way (although not necessarily in an equal and just level playing field). When one jurisdiction fails, it seems to activate the other one. Therefore, in his opinion, it is not unusual that those who are not satisfied by the decisions of Indigenous justice to attempt to activate ordinary justice, and at the same time, those who reject the decisions of ordinary courts can trigger the involvement of Indigenous courts. ${ }^{47}$

45 Von Benda-Beckmann, supra n. 38 at 117.

46 Ávila Linzán, supra n. 41 at 412-413.

47 Agustín Grijalva, "Conclusiones de todos los estudios: experiencias diversas y convergentes de la justicia indígena en el Ecuador", in Justicia INDÍGENA, PLURINACIONALIDAD E interculturalidad en Eguador [Indigenous Justice, Plurinationality and Interculturality in Ecuador] 551, 554 \& 567 (Boaventura de Sousa Santos \& Agustín Grijalva eds., Abya Yala 2012). De Sousa Santos (supra n. 31 at 49) argues that citizens living in a legally pluralistic society may decide to use one legal system in certain "dimensions" of their lives (marriage, inheritance, divorce, domestic violence, custody over children), and another legal system in other "dimensions". "The specific practices of coexistence or articulation between the two [legal systems] carried out by the population are numerous and reveal social and cultural creativity well beyond what can be legislated" (author's translation). Forum shopping would thus seem to be available not only for Indigenous individuals, but for non-Indigenous individuals as well. García and Beltrán report cases of Indigenous adjudicators deciding on disputes where a non-Indigenous person was a party (García, Experiences of Two Communities, supra n. 32 at 73-74; Bolívar Beltrán, El proceso penal indígena: desde el delito hasta la sanción [The Indigenous Criminal Process: From the Crime to the Punishment], 12 AvUARIo de Derecho Constitucional LATINOAMERICANO, 807, 810 (2006). The same was reported by "Efraín", an Indigenous leader (interview, 13 March 2014). Nevertheless, since Ecuador has not passed a law on the coordination and cooperation between the Indigenous and the ordinary justice, the jurisdiction ratione 
In criminal law cases, the choice of forums could stem from an effort to try to avoid jail time for serious crimes. Indigenous legal systems in Ecuador do not use prison as punishment, because it is considered useless. The aims Indigenous justice are said to have include truth-finding, redressing victims and avoiding retaliation from the victims' families, recovering the harmony within the community, and "curing" the accused. ${ }^{48}$ To accomplish these goals, those who are found guilty must apologize in public, compensate the harm, and depending on the crime, receive a cleansing bath with ice-cold water, be whipped or receive other types of corporal punishment, do communal work, or be expelled from the community temporarily or even definitively if the adjudicators believe that the offender cannot be rehabilitated. The choices available would then be, on the one hand, to stand trial in an Indigenous forum and, if found guilty, being convicted to sanctions not involving jail time, or, on the other hand, to stand trial in an ordinary court and, if found guilty, face imprisonment.

Some individuals are well aware of the choice between Indigenous sanctions and ordinary jail-time punishment, and when the moment comes they seek to maximise their benefit. For example, on June 2012, Nelson assaulted a 13 year old girl in her own house. Nelson was found guilty of the crime of rape by an ordinary criminal court and convicted to 16 years of criminal imprisonment. Once Nelson learned the punishment, he self-identified as an Indigenous man and managed to convince Indigenous leaders of a Cayambi Indigenous community to request the ordinary court to refer Nelson's case to the Cayambi Indigenous adjudicators. The ordinary court accepted the request and the case was sent to the Indigenous justice system. Nelson was found guilty again by the Indigenous adjudicators, but this time he got a different punishment. Nelson received in total six lashes. He had to take a cleansing bath with stinging nettles, aromatic smoke and rose petals. He had to pay US $\$ 10,000$ to the victim's family, turn over US\$8,000 for the purchase of a property for the victim, and US $\$ 2,000$ for the victim's psychological treatment. Finally, Nelson was sentenced to six years of communal work. ${ }^{49}$

personae of Indigenous adjudicators is still under debate. I express my position on this issue in Oswaldo Ruiz-Chiriboga, Finding the Right Judge: Challenges of Furisdiction between Indigenous and Ordinary Adjudicators in Ecuador, 49 (1) The Journal of Legal Pluralism and Unofficial Law 3 (2016).

48 Fernando García, El derecho a ser: Diversidad, identidad y cambio [The Right to Be: Diversity, Identity and Change] (FLACSO 2004); Carlos Poveda Moreno, Furisdicción indígena. Reconocimiento de derechos, exigibilidad de obligaciones [ndigenous Jurisdiction. Recognition of Rights, Enforceability of Obligations], 8 FORO 179 (2007); Diego Zambrano Álvarez, Justicias ancestrales: analogías y disanalogías entre sistemas jurídicos concurrentes [Ancestral Justices: Analogies and Dysanalogies between Concurrent Legal Systems], in Derechos ancestrales: Justicia eN CONTEXtos PluRinacionales [Ancestral Rights: Justice in Plurinational Contexts] 219 (Carlos Espinosa \& Danilo Gaicedo eds., Ministerio de Justicia y Derechos Humanos 2009).

49 El Universo, "Acusado de violación se declaró indígena para evitar la justicia ordinaria" 
Nelson's case and similar cases of the rape of children and the elderly received the attention of the national media and several critics. ${ }^{50}$ For instance, "Irene," a feminist activist, said: "it was outrageous to see how a rapist bathes with cold rose water, as part of the punishment! That is a message, a meaning and a terrible symbolism of what rape means to women". ${ }^{51}$ As a result, the Judicial Council (Consejo de la Judicatura), which oversees the functioning of the ordinary Judicial branch, opened administrative proceedings against the judges from this system who referred the cases to Indigenous adjudicators, and the President of the Judicial Council publicly requested the Parliament to pass the Coordination Act mandated by the Constitution, and to define the jurisdiction of the Indigenous justice. ${ }^{52}$ That Act has not yet been adopted. Both the feminist activist and the President of the Judicial Council criticized Nelson's case because they believed his crime remained in impunity.

When a forum is perceived to favor one of the parties, its impartiality could be questioned. For instance, "Carlos", a first instance judge in the ordinary justice system, explained that during his two years in office in a region where the Indigenous population is high, his ideas on the Indigenous justice gradually changed. In Carlos' opinion, the party seeking justice would be the one that presented the complaint in his office, and the party that wanted to escape justice or was afraid of a penalty was the one activating Indigenous justice and demanding Indigenous leaders request the ordinary judge relinquish jurisdiction and refer the case to the Indigenous forum. In the judge's words:

When I arrived at this court [...] I used to think that the Indigenous justice was good. Who would be better to solve their problems than themselves! I used to [think that] if I have a problem in my family, who better to solve the problem but ourselves. I was saying the same regarding Indigenous justice: they should solve their own problems. So I came with high expectations of collaboration and coordination with Indigenous justice. It was good, I thought it was very good. However, since I have been here, they have requested I relinquish my jurisdiction, and absolutely all the requests have come from the debtor who did not want to pay. The debtor who did not want to pay, he wants me to relinquish my jurisdiction. The lawbreaker, the one who punched someone else, the one who stole, they want me to relinquish my jurisdiction. The one that doesn't want to go to prison, they're the one who wants me to relinquish my jurisdiction. The father who owes child support and cannot pay or doesn't want to pay, he wants the relinquishment of my jurisdiction. Ultimately, the person who wants to benefit from something or

[Accused of rape declared himself Indigenous to avoid ordinary justice], 19 May 2013; El Telégrafo, "Reforma urgente a la justicia indígena genera debate" (Urgent reform to Indigenous justice generates debate], 30 May 2013.

50 Id.

51 "Irene", interview, 2014 (author's translation).

52 El Universo, "Jalkh pide a la Asamblea aclarar norma sobre justicia indígena" [Jalkh asks Parliament to clarify provision on Indigenous justice], 28 May 2013. 
wants a more benevolent penalty is the one requesting the relinquishment of jurisdiction. The others did not ask me to relinquish, rather, the other parties rather oppose the request [...] Justice is called into question, the impartiality of the Indigenous authorities gets questioned, the objectivity of the Indigenous justice, their disinterest. I do not like this! [...] To ordinary justice comes the one who wants to be paid, the one who feels wronged. But to Indigenous justice, to trigger Indigenous justice, goes the person fearful of facing a penalty. $\mathrm{He}$ is the one activating Indigenous justice, the one who urges Indigenous authorities to request me to relinquish my jurisdiction". 53

Carlos' impression is confirmed by ethnographic studies ${ }^{54}$ that argue that in certain localities young Indigenous women seem to have more trust in the ordinary justice system than in the Indigenous system. ${ }^{55}$ Cases involving domestic violence, divorce, paternity disputes, and child support are submitted to the ordinary justice system by Indigenous women, "who are becoming aware that solutions can be found in places outside the Indigenous justice". ${ }^{56}$ Choosing the ordinary forum is not well perceived by the male members and it goes against the customs of the community, but nevertheless, women search for a different solution from their own justice, an attitude that "could force a review of the community rules". ${ }^{57}$

Indigenous women, however, do not always succeed in getting protection in a different forum. Lavinas Picq discusses the case of an Indigenous woman, Nono, who repeatedly suffered mistreatment by her husband, Remache, an important Indigenous leader of their locality and a congressman in the national Parliament at the time. "Whenever Nono tried to report violence in the community, she was told that this was a personal matter to be solved

53 "Carlos," interview, 2014 (author's translation).

54 Judith Salgado, Violencia contra las mujeres indígenas: entre las 'justicias' y la desprotección. Posibilidades de interculturalidad en Ecuador [Violence against Indigenous Women: Between 'Justices' and the Lack of Protection. Possibilities of Interculturality in Ecuador], 6 ANUARIO DE ACCIÓN Humantaria r Derechos Humanos 61 (2009); Rachel Sieder \& María Teresa Sierra, M.T, Indigenous Women's Access to Fustice in Latin America, CMI WORKING PAPER (2010), available at http:// wrwre.cmi.no/publications/publication/?3880=Indigenous-womens-access-to-justice-in-latin; García, Do Not Go Crazy, supra n 32, Manuela Lavinas Picq, Between the Dock and a Hard Place: Hazards and Opportunities of Legal Pluralism for Indigenous Women in Ecuador, 54 (2) LATIN AMERICAN POLITICS AND SOCIETr 1 (2012).

55 The word "certain" is italicized to highlight that it is not in all localities that women have more trust in the ordinary justice system. Informal conversations conducted in the field for this research show that in certain localities women in fact prefer to send their cases to the ordinary forum, but there are localities where women were satisfied with their Indigenous forum and which have women as members of the adjudicating body. As a matter of fact, ordinary Indigenous peoples do not always think in terms of a dichotomy between the Indigenous and the ordinary systems, but in terms of "interlegality" (Simon Thomas, supra $\mathrm{n} 4$ ).

56 García, Do Not Go Crazy, supra n 32 at 545 (author's translation).

57 García, Experiences of Two Communities, supra n 32 at 106 (author's translation). 
within her home. Yet, she found little support to secure her well-being." Nono denounced Remache before the ordinary justice system, but Remache, his lawyers, and several Indigenous leaders strongly argued that the case had to be handled by the Indigenous justice system. After being pressured by her in-laws, Nono dropped the charges in the ordinary system, while Remache remained unpunished. Lavinas Picq concluded that this case "reveals how Indigenous justice can be used as a tool to shield the accused from accountability instead of protecting victims". ${ }^{59}$

Leaders or persons close to them being shielded from prosecution was also reported by "Bolívar," a lawyer who has been studying the Indigenous justice and supporting Indigenous communities for a long time. He recognised that there is corruption in some communities where lawyers use Indigenous leaders to have prisoners released from jail, the result of these practices being impunity. ${ }^{60}$ Similarly, Llasag Fernández, an Indigenous lawyer, claims that some Indigenous authorities are being used by political parties in response to particular interests. ${ }^{61}$

The lack of clear rules on jurisdiction offers an opportunity for forum shopping, with all the accompanying possibilities of injustice and impunity. At the same time, this can also create an opportunity for forum selection that could enhance efficiency, or advance the rights of vulnerable or marginalized groups or individuals in Indigenous communities. Everything depends on who is doing the shopping. Is it a rapist who wants to avoid prison? Is it an abusive husband or the corrupt leader who wants to be shielded from prosecution? Or is it a victim of domestic violence who has not received a solution to her problem? Is it a mother who has not received alimony or child support for several months and does not have enough resources to feed her children? Was the decision-making process conducted individually, within the family, or within a subsection of the main group? These type of questions are im-

58 Lavinas Picq, supra n 54 at 5.

59 Id at 7.

60 "Bolívar", interview, 2014.

61 Raúl Llasag Fernández, Fusticia indígena ¿delito o construcción de la plurinacionalidad?: La Cocha [Indigenous Justice, Crime or Construction of Plurinationality?: La Cocha], in Justicia INDÍGENA, PLURINACIONALIDAD E INTERCULTURALIDAD EN EGUADOR [Indigenous Justice, Plurinationality and Interculturality in Ecuador] 321, 326-327 \& 368-369 (Boaventura de Sousa Santos \& Agustín Grijalva eds., Abya Yala 2012) (holding that individuals with economic or political power use the Indigenous justice to get political benefits for them and their allies. The author mentions specifically the case of Lourdes Tibán, an Indigenous lawyer who has a strong political relevance in her province, Cotopaxi, who has economic power, and who was related to the President of the Movimiento Indigena de Cotopaxi (Indigenous Movement of Cotopaxi). Additionally, the author describes that in the La Cocha Indigenous community a section of the leadership supported the political party Alianza País, while another section supported the party Pachakutik. According to the supporters of Alianza País, Pachakutik was advising the Indigenous authorities who administer justice, and therefore the authorities were being used to foster private interests). 
portant to pose, so as to clarify whether the parties' right to access justice has been enhanced or diminished.

As to shopping forum, to encourage the use of the Indigenous justice system as a way of recovering or strengthening an important feature of one's culture is one thing. Another altogether is capturing cases to propel political, economic, or religious interests in favor of the few. Moreover, as will be explained in the next section, the administration of Indigenous justice is conceived of as a collective right of Indigenous nations, but such a collective right does not imply absolute discretion of Indigenous adjudicators. Their discretion is limited by the individual right of community members to access to justice. Having discretion means having a choice, and when adjudicators decide which cases they are going to hear, they are "shopping" for the controversies they want to handle while ignoring others, which could have serious impacts on the individuals whose cases were not selected.

\section{To Hear or Not to Hear a Case, That is The Question}

Article 57(10) of the Constitution provides that the State recognizes and guarantees to Indigenous communities, peoples and nations, in accordance with the Constitution and with the covenants, agreements, declarations and other international instruments on human rights, "the right to create, develop, apply, and practice their own customary law". ${ }^{62}$

Indigenous justice is a collective right, but the discretion the Indigenous nations have in deciding whether to exercise this right is not absolute. Members of Indigenous communities also have the right to access to justice as individuals, including to access their own legal system. In other words, the collective right of an Indigenous group to use and apply their laws is limited and reinforced by the individual right of members of the group to access to their own legal system. Both rights reinforce each other in the sense that both point to the direction of recognising Indigenous law as an adequate venue to resolve conflicts, a venue that respects and reinforces the culture, social organization and autonomy of Indigenous peoples. But the individual rights of the members of the community also serve as a limit to collective rights. For instance, every person whose human rights have been violated is entitled to obtain clarification of the events that led to the violation of human rights and the corresponding responsibilities, through the investigation and prosecution of those responsible. ${ }^{63}$ Individuals have the right

62 Constitution, supra n 17, Art. 57(10).

63 IACHR, Barrios Altos v. Peru. 2001, para. 48. 
to go to a tribunal when any of [their] rights have been violated, to obtain a judicial investigation conducted by a competent, impartial and independent tribunal that will establish whether or not a violation has taken place and will set, when appropriate, adequate compensation. ${ }^{64}$

Implicit in the collective right of Indigenous nations to administer justice is the individual right members of their communities have to demand their authorities resolve conflicts through the application of their customs, culture and customary laws by their own competent authorities. International human rights law provides that the right to be heard by a competent judge is one of the basic due process of law guarantees states must offer to individuals in order to achieve a fair trial. ${ }^{65} \mathrm{In}$ fact, the right to be heard by a competent judge is not only a basic principle of due process of law ${ }^{66}$ but a pre-condition of it. ${ }^{67}$ When an incompetent judge hears a case, "there was no due process, given a failure of an essential nature, and that no actions taken in such conditions could have produced [...] legal effects". 68

It is not the task of international law to define who should be the competent judge. This is the exclusive duty of national law. As the Inter-American Court of Human Rights (IACHR) put it, "the existence and jurisdiction of the competent tribunal derive from the law". 69 The only requirement international law sets is that individuals have to be tried by courts or tribunals using established legal procedures. "Tribunals that do not use the duly established procedures of the legal process shall not be created to displace the jurisdiction belonging to the ordinary courts or judicial tribunals". ${ }^{70}$ Remov-

64 Inter-American Commission on Human Rights, Raquel Martín de Mejía v. Peru, 1996, p. 22.

65 For instance, the American Convention on Human Rights (ACHR), 22 November 1969, O.A.S.T.S. No. 36, 1144 U.N.T.S., Art. 8(1) states: "Every person has the right to a hearing, with due guarantees and within a reasonable time, by a competent, independent, and impartial tribunal, previously established by law, in the substantiation of any accusation of a criminal nature made against him or for the determination of his rights and obligations of a civil, labor, fiscal, or any other nature". The International Covenant on Civil and Political Rights (ICCPR), 16 December 1966, 1916 U.S.T. 521999 U.N.T.S. 171, Art. 14(1) states: "All persons shall be equal before the courts and tribunals. In the determination of any criminal charge against him, or of his rights and obligations in a suit at law, everyone shall be entitled to a fair and public hearing by a competent, independent and impartial tribunal established by law".

66 IACHR, Castillo Petruzzi et al. v. Peru, 1999, para. 129; IACHR, Lori Berenson Mejía v. Peru, 2004, para. 143, IACHR, Palamara Iribarne v. Chile, 2005, para. 125.

67 IACHR, Barreto Leiva v. Venezuela, 2009, para. 75.

68 IACHR, Separate Opinion of Judge García Ramírez, Usón Ramírez v. Venezuela, 2009, para. 10 .

69 Id para. 76.

70 Principle 5 of the Basic Principles on the Independence of the Judiciary, adopted by the Seventh United Nations Congress on the Prevention of Crime and the Treatment of Offend- 
ing individuals from their natural courts and referring their cases to special courts, for instance, to military tribunals, has been determined to be a violation of the right to a fair trial. ${ }^{71}$

Consequently, there would be a violation of the right to be heard by a competent court if an individual who was supposed to be heard by an Indigenous legal system is brought to the ordinary justice system, or vice versa. If such a violation is detected, the proceedings would be invalid, because one of the pre-conditions - the competence of the judge - was not met. This demonstrates the importance of determining who the competent judge is: the validity of the entire procedure rests on the competence of the adjudicator.

At the same time, the individual right to be heard by an Indigenous adjudicator should not be absolute. In certain cases, good reasons could be brought forward by the community in order to refuse to hear a particular case (for instance, the protection of community cohesion). Therefore, the discretion of adjudicators in deciding whether they are able or willing to resolve a conflict should be carefully exercised and balanced with the individual right to access a particular legal system. Indigenous authorities should give good reasons if they decide to refer the dispute to the ordinary justice system. García mentions that the decision to send a case to the ordinary justice system should be agreed upon by the adjudicators and the parties. ${ }^{72}$ It goes without saying that if Indigenous authorities refuse to hear a case, they should not prevent the individual from searching for justice in another Indigenous forum or in the ordinary system. The worst case scenario would be that the individual, having access to multiple forums, is not heard by any of them.

Practices in this regard are heterogeneous. "Efraín" mentioned that only in extreme cases, usually involving serious crimes, he and other Indigenous authorities decide to refer the case to the ordinary justice system. "We entrust [the case] to you, Mr Prosecutor, Judge. We've come this far,” were Efraín's words. ${ }^{73} \mathrm{He}$ also mentioned that it was very risky for them to attempt to solve every type of conflict, because his community was still in a process of reconstructing and strengthening its customary law.

I was told that in some communities, everyone knows that certain issues are not heard by the Indigenous authorities, either because the authorities have no expertise in resolving those issues, because the conflicts are too serious to be handled in the "mediation style" 74 Indigenous adjudicators use,

ers held at Milan from August 26 to September 6, 1985 and endorsed by General Assembly resolutions 40/32 of 29 November 1985 and 40/146 of 13 December 1985; IACHR, Barreto Leiva v. Venezuela, 2009, para. 75.

71 IACHR, Loayza Tamayo v. Peru, 1997; IACHR, Castillo Petruzzi et al. v. Peru, 1999; IACHR, Durand and Ugarte v. Peru, 2000; IACHR, Radilla Pacheco v. Mexico, 2009.

72 García, Experiences of Two Communities, supra $\mathrm{n} 32$ at 70.

73 "Efraín”, Indigenous leader, interview, 2014.

74 Ramiro Ávila Santamaría, ¿Debe aprender el derecho penal estatal de la justicia indígena? [Should the State Criminal Law Learn from the Indigenous Justice?], in Justicia Indígena, PLuRINA- 
or because there has been a decision by leaders that it is better for the community's stability and cohesion to refer specific cases to the ordinary system. "Mesías" mentioned that his community does not hear paternity disputes and child support disputes. ${ }^{75}$ "Homero," an Indigenous lawyer working at the Public Prosecutor's Office on Indigenous Affairs, ${ }^{76}$ said that in his locality rape was very rare, and because of that the few cases that occurred in Indigenous settlements were referred to his office..$^{77}$ Mario Melo, an activist and academic, commented that when a murder occurs in Sarayaku territory, the leaders expel the murderer from the community and at the same time they refer the case to the ordinary justice system. ${ }^{78}$ In Melo's opinion, that is a valid decision, based on community self-determination. ${ }^{79}$

There is also the possibility that Indigenous authorities work with authorities in the national justice system. "Pepe," an Indigenous lawyer who works at the Public Prosecutor's Office on Indigenous Affairs, ${ }^{80}$ sometimes receives criminal complaints concerning Indigenous individuals. Pepe is a public prosecutor and has at his disposal all the investigative tools of the Public Prosecutor's Office (laboratories, crime scene investigators, etc.). He starts the investigation, and when he has enough evidence against the alleged perpetrator, he presents his results not to an ordinary judge, but to the Indigenous adjudicators of the perpetrators' locality, so that they can hold a hearing and decide on the guilt of the suspects. Pepe proceeds in this way every time he believes

CiONALIDAD E INTERCUlturalidad EN ECUAdor [Indigenous Justice, Plurinationality and Interculturality in Ecuador] 279, 300 (Boaventura de Sousa Santos \& Agustín Grijalva eds., Abya Yala 2012). (This paper argues that in Indigenous justice the great majority of conflicts are resolved through conciliation); Simon Thomas, supra n 4, states that Indigenous customary law is not only about norms but it also involves agreements, and the litigants may choose the local authorities and select the procedures these authorities may use.

75 "Mesías", Indigenous leader, interview, 2014. See also, Simon Thomas, supra n 4, who after reviewing judicial archives in ordinary courts, states that three out of four cases concerning people living in the Indigenous parish he studied were about child support.

76 In 2007, the Public Prosecutor's Office (Fiscalía General del Estado) created the Public Prosecutor's Office on Indigenous Affairs (Fiscalia de Asuntos Indígenas). This office has eleven Indigenous prosecutors that speak the Indigenous language of the localities they serve (see, Public Prosecutor's Office No. 064 MFG-2007, 8 November 2007, and Simon Thomas supra $\mathrm{n}$ 4). These Indigenous prosecutors are part of the ordinary justice system and they report their findings to ordinary courts. However, I interviewed "Pepe", an Indigenous prosecutor who sometimes reports his findings to Indigenous forums (see infra $\mathrm{n} .80$ and accompanying text).

77 "Homero," interview, 2014.

78 It could be argued that there is a violation of the ne bis in idem rule in this type of case. The defendants are expelled from the community because they are regarded as guilty of the crime of murder, the expulsion being a sanction passed in the Indigenous forum. If the defendants' case is referred to the ordinary justice system, they would be tried again based on the same facts (see infra Section IV).

79 Mario Melo, interview, 2014.

80 "Pepe," interview, 31 March 2014. 
the Indigenous forum has jurisdiction to hear the dispute. In his legal-anthropological research in Ecuador's highlands, Simon Thomas discussed a case where the parties, both of them Indigenous, solved an adultery case using traditional ways of dealing with conflicts, but before a Teniente Politico, an appointed political official from the ordinary system. Simon Thomas concluded that the line between customary law and Ecuadorian national law is in practice rather blurred. ${ }^{81}$

The coordination between authorities is not always easy or even planned. "Miguel", an Indigenous leader, ${ }^{82}$ recounts a case in which a man was accused of murdering his wife. Both the perpetrator and the victim were Indigenous, but the case was in the hands of a public prosecutor from the ordinary justice system. The family of the victim, tired of waiting for the prosecutor to accuse the alleged perpetrator and outraged to see him walking free, petitioned Miguel and his fellow Indigenous authorities to intervene in the matter. Miguel and the other authorities, without challenging the jurisdiction of the public prosecutor, started their own investigation (this being a good example of simultaneous forum shopping). After questioning the suspect for three days, he confessed to the crime and gave details of important evidence (including the location of the clothes he wore during the murder, which were covered with the victim's blood). With all that evidence, Indigenous authorities went to the prosecutor's office, and according to Miguel:

We clearly said to the prosecutor and the police: 'What have you done so far? These are our results. Here's the suspect. Take a good look at him so you do not demonize us saying that we had punished him. Here is the person, completely healthy and safe. There he is. You check.' They looked at him, and then we continued: 'Mr Prosecutor we leave this individual in your hands.' The daughters did not allow their father to stay at home. They said, 'how are we going to live with a criminal in the house. Suppose that he kills us too'. We didn't even think of sending him to jail. No. Because of the daughters and other relatives insisted: 'he has to go to jail, we do not want him here.' Because of that we told the prosecutor: 'Mr Prosecutor here he is, and here's our job, the report in writing of all our activities. Here Mr Prosecutor, that's how it's done!"”.

Indigenous adjudicators or the parties may not only seek the support of the ordinary system, but for also the support of Indigenous authorities from other communities. "They ask us to do them the favor of solving their conflict", was a phrase I heard from several Indigenous respondents. Similarly, Simon Thomas studied a murder case in Zumbahua, in which the suspects all originated from Guantópolo, but it was solved in La Cocha. The authorities of Guantópolo believed that the authorities of La Cocha had more expertise

81 Simon Thomas, supra $\mathrm{n} 4$.

82 "Miguel," interview, 2014. 
in murder cases, and the La Cocha community seemed to offer more guarantees of impartiality. ${ }^{83}$

It is also possible that Indigenous leaders remain passive. Kurikama Yupanki, an Indigenous lawyer working on Indigenous justice, mentioned that he personally knew several communities where the president of the cabildo (the organization of Indigenous leaders that among other activities administers justice) remained inactive regarding certain cases, but acted with diligence in others, the only difference being whether the cases were considered interesting or not. In an interview, Mr Yupanki recalled a dialogue between himself, a community member and the president of a cabildo:

"There are presidents who run when something is of their interest, but when they do not care, they don't do it!" [A community member talking to Mr Yupanki] 'Compañero (comrade), five months ago we ask the president to do [justice]. He didn't do it! He didn't do justice!' And some even say 'companero, I have begged so much for him [the president] to do me a favor, and he doesn't want to do me a favor'. I say [to the president of the cabildo]: 'excuse me! Dammit! How come you do not want to do them a favor? You don't have to do favors! You, according to the Constitution, must be the authority. According to the Constitution, you are the authority, you must do justice!' [With a sarcastic voice and imitating the president] 'I don't want to do them a favor, I don't want to do them a favor!' And this happens in many communities! ${ }^{84}$

The examples mentioned above demonstrate two possible outcomes of shopping forums. Having different forums could, in fact, foster individual access to justice and respect the autonomy of Indigenous communities. If for good reasons the Indigenous adjudicators are unwilling or unable to solve a controversy, the authorities or the parties involved may seek the support of the ordinary justice system or other Indigenous forums. But if there are no good reasons for the Indigenous authorities to abstain from resolving the controversy, a pernicious effect could occur. The Indigenous forum could be shopping for disputes that are important or relevant for the adjudicators, either because one or both of the parties are influential or well-connected persons within the community, or because the controversy is attractive enough

83 According to Simon Thomas, "the five suspects were captured by local residents and handed over to the cabildo of La Cocha, another neighbouring community. This was an interesting aspect of the case, given that the community of Guantópolo has a cabildo of its own. But, those who captured the five young men probably either knew or suspected that at least one of them was related to a member of the cabildo of Guantópolo and therefore might receive preferential treatment in that community. A second reason not to hand the five suspects over to the cabildo of Guantópolo, was that it had absolutely no experience with serious crimes such as homicide. On the other hand, because of its exemplary handling of a murder case in 2002, the cabildo of La Cocha was considered to be the most trustworthy authority in such a serious legal matter" (Marc Simon Thomas, Legal Pluralism and the Continuing Quest for Legal Certainty in Ecuador: A Case Study from the Andean Highlands, 7(2) Or̃ati SocIo-LEGAL SERIES, 57, 71 (2012).

84 Kurikama Yupanki, interview, 4 April 2014 (author's translation). 
to expend some time solving it, because the authorities are in the mood for "doing favors" to those who seek their intervention. Conflicts involving community members with no political or economic influence, without any extra parte repercussion, or whose cases are not attractive enough, could be discarded by the Indigenous authorities in an unfair and illegitimate use of their jurisdictional discretion. If the affected individuals lack the means to turn to the ordinary justice system or if they are unable to convince other Indigenous forums to solve the dispute, their right to access justice would be illegitimately violated. As mentioned above, the worst possible scenario would be to have multiple forums available to solve disputes, but for none of them actually solve the case.

\section{The $\mathcal{N}_{\text {e }}$ Bis IN Idem Rule: a Failed Attempt to Limit the Possibility of Forum Shopping?}

This section will discuss the ne bis in idem ${ }^{85}$ rule as a mechanism originally intended to limit forum shopping and shopping forums. The first attempt to apply the rule was the La Cocha 1 first instance judgment, which decided that the ordinary forum should not hear the case because it had already been resolved by an Indigenous forum. The judgement was quashed in appeal, but it contributed to the debate on the issue. The Constitution of 2008 recognized the ne bis in idem rule as a way of limiting the action of one system if the other has already decided the case. However, the Constitutional Court in La Cocha 2 emitted an interpretation that opened the possibility of a second trial.

\section{La Cocha 1 Murder Case: The First Attempt to Apply the Ne Bis In Idem Rule}

On 21 April 2002, Maly was murdered in the Indigenous community of La Cocha. Indigenous authorities conducted inquiries and investigations, after which, on May 5, 2002, the community's General Assembly, its highest authority, determined that Nicolas, Juan and Jaime were responsible for Maly's death. ${ }^{86}$ The three wrongdoers were punished according to Indigenous customary law. ${ }^{87}$ Two months later, on July 3, 2002, a public prosecutor from the

85 "Not twice for the same".

86 Constitutional Court, Judgement No. 0002-2003-CG, 2003.

87 The customary sanctions included: a cleansing bath with ice-cold water, rubbing with stinging nettles while receiving advice, US\$6,000 as compensation to the widow and her children, public apologies, and expulsion from the community for two years (Fernando García, $E l$ estado del arte del derecho indígena en Ecuador [The State of the Art of Indigenous Law in Ecuador], 41 Revista IIDH 151, 153 (2005); Marc Simon Thomas, Legal Pluralism and Interlegality in Ecuador. The La Cocha Murder Case, 24 CUADERNos DEL CEDLA 1, 64-65 (2009). 
ordinary justice system decided to open a criminal investigation against the wrongdoers, disregarding that they already received punishments according to the Indigenous system. On September 9, 2002, a public hearing was conducted before Mr Poveda, the criminal judge appointed to the case. ${ }^{88}$ Judge Poveda passed his judgement the next day. He declared that the case had already been resolved by the Indigenous authorities of La Cocha and that the ne bis in idem rule had to be applied. ${ }^{89}$ The public prosecutor appealed Judge Poveda's decision arguing that the ordinary forum and not the Indigenous forum had jurisdiction over the matter. The case was referred to the Court of Justice of Cotopaxi (Corte Superior de Cotopaxi), which agreed with the prosecutor and quashed Judge Poveda's ruling, sending the case back to the first instance court. The new first instance judge appointed to the case decided to convict the three wrongdoers to imprisonment according to Ecuador's Criminal Code. Nevertheless, the three men were never apprehended. Two of them returned to the community where they were rehabilitated and offered economic assistance to Maly's widow. ${ }^{90}$

Judge Poveda's ruling, although it was not confirmed in appeal, provided food for thought to the arguments for ${ }^{91}$ and against the application of the ne bis in idem. ${ }^{92}$ In 2008, with the adoption of the current Constitution, this issue was settled. Article 76(7)(i) of the 2008 Constitution provides that "no one shall be tried more than once for the same cause and matter. The cases decided by Indigenous jurisdiction should be considered for this purpose" ${ }^{93}$ The new Organic Code of the Judiciary reinforced that rule by stating in Article 344: "the decisions of the authorities of Indigenous justice shall not be reviewed by the judges of the Judiciary or by any administrative authority, at any stage of the proceedings, without prejudice of constitutional review". ${ }^{94}$ Finally, Article 5(9) of the new Criminal Code states: "no person shall be tried

88 García, supra n 87 at 153.

89 Juzgado Tercero de lo Penal de Cotopaxi [Third Criminal Court of Cotopaxi], Case No. 43-2002, Judgment, 10 September 2002. A transcript of this judgement can be found in Luis Fernando Sarango, La administración de justicia indígena en el Ecuador. Una práctica ancestral con reconocimiento constitucional [The Administration of Indigenous Justice in Ecuador. An Ancestral Practice with Constitutional Recognition], 5 YACHAYKUNA 53, 92-102 (2004).

90 Simon Thomas, supra $\mathrm{n} 87$ at 70-71.

91 García, supra n 87; Marcelo Bonilla Urvina, Pluralismo jurídico en el Ecuador. Hegemonía estataly lucha por el reconocimiento de la justicia indígena [Legal Pluralism in Ecuador. State Hegemony and Struggle for the Recognition of Indigenous Justice], in HACIA SISTEMAS JURÍDicos PLURALES. REFLEXIONES Y EXPERIENCIAS DE COORDINACIÓN ENTRE EL DERECHO ESTATAL Y EL DERECHO INDÍGENA [Towards Plural Legal Systems. Reflections and Experiences of Coordination between State Law and Indigenous Law] 51 (Rudolf Huber ed, Konrad Adenauer Stiftung 2008).

92 Rubén D. Bravo Moreno, La justicia indígena y el principio non bis in idem [Indigenous Justice and the ne bis in idem principle], Derecho Ecuador (2005), available at https://wwer.derechoecuador.com/ la-justicia-indiacutegena-y-el-principio-non-bis-in-idem .

93 Constitution (2008), supra n 17.

94 Organic Code of the Judiciary, supra n 27. 
or punished more than once for the same facts. The cases decided by Indigenous jurisdiction are considered for this purpose". 95

Ecuadorian law seemed to be very clear in stopping sequential forum shopping. The general ne bis in idem constitutional rule covers all cases of double jeopardy, whether the deciding authority is Indigenous or not. For the Constitution, it suffices that the "cause" or "matter" is the same to trigger the ne bis in idem rule. It is equally forbidden for Indigenous adjudicators to hear a case already tried by ordinary adjudicators, as well as for ordinary adjudicators to hear a case already tried by Indigenous adjudicators. The Criminal Code goes even further by prohibiting double trial or punishment on the basis of the same "facts". Unlike the Constitution and the Criminal Code, the Organic Code of the Judiciary only prohibits double jeopardy if the first deciding authority was an Indigenous one. The Organic Code of the Judiciary remains mute regarding cases where the first deciding authority is from the ordinary justice system.

The only exception to the prohibition of ordinary judges reviewing the decisions of Indigenous adjudicators is the constitutional review the Constitutional Court carries out when an individual submits a "motion for extraordinary protection" (acción extraordinaria de protección). According to Article 65 of the Organic Law on Jurisdictional Guarantees and Constitutional Control (Ley Orgánica de Garantías Furisdiccionales y Control Constitucional), "those who were dissatisfied with the decision of an Indigenous authority exercising judicial functions, for violating constitutionally guaranteed rights or discriminating against women for being women, may appeal to the Constitutional Court and present a challenge to that decision, within the term of twenty days after the decision was made known". ${ }^{96}$

This exception has not been exempt from criticism. If both legal systems are on equal footing, as some argue, ${ }^{97}$ why should the Constitutional Court, which belongs to the ordinary justice system, control the decisions of the Indigenous systems? Wouldn't this mean that in practice the ordinary system has a higher rank than Indigenous systems? De Sousa Santos writes that in

95 Organic Integrated Criminal Code (Código Orgánico Integral Penal), R.O. No. 180, 10 February 2014.

96 Organic Law of Judicial Guarantees and Constitutional Control (Ley Orgánica de Garantías furisdiccionales y Control Constitucional), R.O. Supp. No. 52, 22 October 2009.

97 Ávila Linzán, supra n 25 at 78; Miguel Hernández Terán, Justicia indígena, derechos humanos y pluRALISMo JuRíDico [Indigenous Justice, Human Rights and Legal Pluralism] 108 (Corporación de Estudios y Publicaciones 2011); Chávez Vallejo, supra n 26 at 82. My respondents held a similar position: "I, for example, as an [Indigenous] authority, as a former president [of the community] and as an ancestral authority, I am at the same level as the [ordinary] judge" ("Efraín," Indigenous leader, interview, 13 March 2014, author's translation); "The constitutional rule is very clear, [...] it states in the last paragraph of [Article] 171 that the decisions of the Indigenous justice must be respected. The principle of equal status of both jurisdictions is implicit" (María Mercedes Lema, Indigenous lawyer and judge in the ordinary justice system, interview, 19 February 2014, author's translation). 
order to overcome this issue, the composition of the Constitutional Court should be modified by appointing experts on Indigenous legal systems. ${ }^{98}$ Baltazar Yucailla goes a step further and argues that the Constitutional Court should have a special chamber on Indigenous collective rights, such a chamber would be composed of "Indigenous professionals who understand the traditions and customs of Indigenous nationalities and peoples in the application of Indigenous justice". ${ }^{99}$ Whether these solutions would enhance mutual cooperation and the understanding of the different legal systems or do the opposite, separating the systems by ethnicity, which could impact professionals, conceptions and values, is a matter that requires further research.

In another murder case in the community of La Cocha (La Cocha 2), the Constitutional Court appears to have created a particular conception of the ne bis in idem rule, allowing Indigenous defendants already sanctioned by Indigenous adjudicators to be tried again by ordinary criminal judges and face the punishments established in the Criminal Code.

\section{La Cocha 2 Murder Case: The Constitutional Court and Its Particular Conception of the Ne Bis In Idem Rule}

On July 30 and September 11, 2014, the Constitutional Court passed two judgments in another murder case decided by the La Cocha community. The case is known as La Cocha 2 to distinguish it from the murder case of Maly (La Cocha 1) described above. The facts of La Cocha 2 are as follows: on May 9, 2010, Marcelo was found dead in the village of Zumbahua, located in the Ecuadorian province of Cotopaxi. The next day, five men suspected of his murder were caught and handed over to Indigenous authorities. In two separate sessions, the General Assembly of La Cocha-Zumbahua found the accused guilty. They all received the same penalties: a fine of US\$5000, a ban from all social and cultural celebrations for two years, expulsion from the community for two years, mandatory subjection to cold baths and stinging nettles for a period of one half-hour, one lash with a leather strap by each communal leader, and the tasks of carrying a hundredweight while seminaked and making public apologies. ${ }^{100}$ Nevertheless, the five defendants were arrested by the national police and put on trial before an ordinary criminal

98 De Sousa Santos, supra n 3 lat 41.

99 Rosa Cecilia Baltazar Yucailla, La justicia indígena en el Ecuador [Indigenous Justice in Ecuador], in Derechos ancestrales: Justicia EN CONTEXTOS PLURINACIONALES [Ancestral Rights: Justice in Plurinational Contexts] 451, 469 (Carlos Espinosa \& Danilo Caicedo eds., Ministerio de Justicia y Derechos Humanos 2009) (author's translation).

100 General Assembly of La Cocha-Zumbahua, Acta (handwritten record) No. 24, 16 May 2010. See also, Simon Thomas, supra n 83 and supra n 4; Llasag Fernández, supra n 31; Carlos Poveda Moreno, La Cocha: 2002-2010: Retrocesos en un estado constitucional de derechos y justicia, social, democrático, soberano, independiente, unitario, intercultural, plurinacional y laico [La Cocha: 2002-2010: 
judge. At the same time, the three Indigenous leaders who heard the case were arrested for kidnapping. Additionally, the brother of the deceased submitted a motion for extraordinary protection before the Constitutional Court challenging the constitutionality of the Indigenous adjudicators' decision.

The case against the Indigenous leaders was allocated to the Fuzgado Tercero de Garantías Penales de Cotopaxi (Third Criminal Guarantees Court of Cotopaxi), while the case against the men accused of murder was allocated to the Tribunal de Garantías Penales de Cotopaxi (Criminal Guarantees Tribunal of Cotopaxi). The Fuzgado decided to suspend the proceedings and send the case to the Constitutional Court to decide on the constitutionality of the proceedings. ${ }^{101}$ In the Juzgado's opinion, the Indigenous leaders were facing criminal charges for performing functions expressly permitted by the Constitution. The Tribunal decided to suspend the proceedings against the men accused of murder and referred the case to the Constitutional Court, asking the following question: "is it possible to indict for a second time Indigenous individuals belonging to an Indigenous community, if they have already been sanctioned by the authorities of that community?" 102

In sum, the Constitutional Court received three different applications: 1) the motion for extraordinary protection submitted by the brother of the deceased, challenging the constitutionality of the decision of the Indigenous authorities; 2) a consultation from the fuzgado deciding on the criminal responsibility of the Indigenous leaders, and 3) a consultation from the Tribunal deciding on the criminal responsibility of the alleged perpetrators of the murder.

On July 30, 2014, the Constitutional Court decided on the application submitted by the brother of the victim, ${ }^{103}$ and on September 11, 2014, it passed a single judgment on the consultations presented by both the Fuzgado and the Tribunal. ${ }^{104}$ In its judgments, the Constitutional Court studied the evidence submitted regarding the legal system of the Indigenous community to which the Indigenous leaders, the victim, and the perpetrators belong. It concluded that when the adjudicators of the Indigenous community resolved the murder case, they did not decide on:

the legally protected value of life as an end in itself, but in terms of the social and cultural effects that the death caused in the community [...], while on the

Setbacks in a Constitutional State of Rights and Justice, Social, Democratic, Sovereign, Independent, Unitary, Intercultural, Plurinational and Secular], 49 NOVEDADES fURIDICAS, 6 (2010).

101 According to Art. 438 of the Ecuadorian Constitution, supra n. 17, when a court, ex officio or upon request, considers that a legal rule is contrary to the Constitution or international human rights instruments, it may suspend the proceedings and refer the case in consultation to the Constitutional Court, for it to decide on the constitutionality of the legal rule.

102 Constitutional Court, Judgment No. 006-14-SCN-CG (author's translation).

103 Constitutional Court, Judgment No. 113-14-SEP-CG.

104 Constitutional Court, Judgment No. 006-14-SCN-CG. 
other hand, the prosecution and the ordinary criminal courts acted under the constitutional and legal obligation to investigate and prosecute, respectively, the individual responsibility of those allegedly involved in the death. ${ }^{105}$

In the Constitutional Court's opinion, there was no violation of the ne bis in idem rule because Indigenous justice was protecting the collective dimension of the right to life, while ordinary justice was protecting the individual dimension of that right. ${ }^{106}$ The Court ruled that: (1) Indigenous authorities committed no violation of national law when they heard and solved the murder case, and therefore the criminal case against them before the fuzgado should be dismissed, and (2) the public prosecutor and the Tribunal committed no violation either in initiating a criminal case against those who were already punished by the Indigenous adjudicators, and therefore the criminal proceedings against the men accused of murder before the Tribunal should continue.

Finally, the Constitutional Court established a general rule applicable to every future case related to Indigenous legal systems. In the Court's view, the ordinary justice system upholds the right to life as a value in itself, while Indigenous legal systems uphold the right to life as a means to contribute to the realization of the community as its highest value. Such a view was insufficient, according to the Constitutional Court, to guarantee the individual right to life as guaranteed in the Constitution, in the international human rights instruments Ecuador has ratified, and in ius cogens norms. ${ }^{107}$ Therefore, the Court ruled that all future cases involving the right to life shall be heard exclusively by the ordinary justice system, with Indigenous authorities no longer having any subject-matter jurisdiction over these cases. ${ }^{108}$

The Constitutional Court's judgment was severely criticized by the Indigenous movement. ${ }^{109}$ Nina Pacari, an Indigenous leader and politician, called the judgment "nefarious and shameful" (nefasta y vergonzosa). ${ }^{10}$ The CONAIE

105 Constitutional Court, Judgment No. 113-14-SEP-CG (author's translation).

106 Constitutional Court, Judgment No. 006-14-SCN-CG.

107 Ius cogens are fundamental principles of international law that are considered by the international community as norms from which no derogation is permitted (see, Alfred Verdross, Jus Dispositivum and Jus Cogens in International Law, 60 American Journal of International Law 55 (1966).

108 Constitutional Court, Judgment No. 113-14-SEP-CG.

109 See for instance, "Dirigentes indigenas exigen nulidad de resolución de la Corte Constitucional" [ndigenous leaders demand the annulment of the Constitutional Court's decision], Ecuavisa, 5 August 2014, available at http://werere.ecuavisa.com/articulo/noticias/nacional/74546-dirigentes-indi genas-exigen-nulidad-resolucion-corte-constitucional.

110 "Nina Pacari: Acerca de cómo comprenden la dominación los Pueblos Indígenas y a los gobiernos progresistas" [Nina Pacari: On how Indigenous peoples understand domination and progressive governments], Periodismo Humano, 13 September 2014, available at http://guatemalacomunitaria. periodismohumano.com/2014/09/13/nina-pacari-acerca-de-como-comprenden-la-dominacion-los-pueblosindigenas-y-a-los-gobiernos-progresistas/. 
announced that it will not respect the Court's ruling. ${ }^{111}$ Sixto Yaguachi, an Indigenous leader from the ECUARURANI (the organization of the Indigenous communities of the Kichwa Nation of Ecuador's highlands), stated: "Whatever they say, whatever they do, we will continue with this disobedience applying our principles because we are supported by our international rights". ${ }^{112}$ Most of the criticism was aimed at the limitation of subject matter jurisdiction in Indigenous legal system, an issue that is beyond the scope of this article. ${ }^{113}$

\section{The Implications of the La Cocha 2 Judgment}

The first and most obvious consequence of the Constitutional Court's ruling is the eradication of forum shopping in criminal cases when the right to life is involved. The disputants no longer have the choice of forums in cases related to Articles 140-149 of the Criminal Code (all forms of murder, manslaughter, feminicide, and abortion). The second consequence, closely linked to the first, is the eradication of shopping forums. The Indigenous forum and the ordinary forum will not have to compete in to attract disputants in rightto-life cases. The Constitutional Court made the "final purchase" and gave the ordinary forum exclusive jurisdiction.

One should bear in mind that this is a legal eradication of forum shopping and shopping forums, but in reality, these phenomena may still occur, despite the Constitutional Court's prohibition. If the Indigenous authorities keep their word by not complying with the Court's decision, Indigenous communities could decide to go "underground" in the administration of their justice, as they did during the centuries that Indigenous legal systems were tacitly permitted but not formally recognized by Ecuador's monistic legal culture. ${ }^{114}$ The outcomes could vary from a complete agreement between the parties to not alert ordinary authorities because they all agree with the solution reached by Indigenous adjudicators, to cases in which powerful defendants could still

111 "CONAIE rechaza fallo de CC sobre justicia indígena y anuncia que se unirá a la marcha del FUT" [CONAIE rejects the CG ruling on Indigenous justice and announces that it will join the march of the FUT], Ecuador Inmediato, 21 August 2014, available at http://ecuadorinmediato.com/in dex.php? module $=$ Noticias $\mathcal{E}^{2}$ func $=$ news_user_viewEं $i d=2818768418 \mathcal{E}^{2} u m t=$ conaie_rechaza_fallo_cc_so bre_justicia_indigena_y_anuncia_que_se_unira_a_marcha_del_fut.

112 "La CONAIE no acatará la sentencia de la CC" [The CONAIE will not abide by the decision of the CG], El Mercurio, 8 August 2014, available at http://wrere.elmercurio.com.ec/442545-laconaie-no-acatara-la-sentencia-de-la-cc/\#.Vcr32vlvIuQ(author's translation).

113 My position on the jurisdiction ratione materiae, personae and loci of Indigenous adjudicators can be found in Ruiz-Chiriboga, supra $\mathrm{n} 47$.

114 Raquel Yrigoyen, The Constitutional Recognition of Indigenous Law in Andean Countries, in The Challenge of Diversity: Indigenous Peoples and Reform of the State in Latin America 197, 206-207 (Willem Assies, Gemma van der Haar \& André Hoekema eds., Thela Amsterdam 2000); Simon Thomas, supra n 87 at 35-38 and supra 42 at 59-60. 
shop for an Indigenous forum while a weak accuser could be pressured to accept an Indigenous forum and be prevented from seeking intervention in the ordinary justice system.

As to the ne bis in idem rule, the Constitutional Court's distinction between the individual and collective dimensions of the right to life creates more problems than solutions. First, it could make the same distinction with regards to many other rights. For instance, the right to personal integrity, which includes the right not to be tortured, ${ }^{115}$ rape cases, ${ }^{116}$ or the prohibition of cruel, inhuman and degrading treatments and punishments, ${ }^{117}$ could also be divided into distinct individual and collective realms. If Indigenous adjudicators solve a right-to-personal-integrity case focusing on the collective dimension of this right, could then ordinary authorities subsequently start criminal investigations to deal with the individual dimension of that right? Like the right to life, the right to personal integrity is a fundamental right protected by the Constitution, ${ }^{118}$ the international treaties Ecuador has ratified, ${ }^{119}$ and the ius cogens rules. ${ }^{120}$ If Indigenous adjudicators solve a right-to-personal-integrity case focusing on the collective dimension of this right, could we then deduce that rape cases shall be also excluded from Indigenous jurisdiction? If one follows the reasoning of the Constitutional Court in La Cocha 2, the answer to this question would be yes. However, the Constitutional Court in a subsequent judgment stated that the only competent forum to deal with right to life cases is the ordinary forum, Indigenous forums being excluded, but in other cases not involving the right to life, ordinary judges "are obliged to stop hearing the case" and refer it to an Indigenous forum if so requested. ${ }^{121}$ The Court did not explain why in these other cases the individual versus collective approach was not applicable.

The second problem with the Court's ruling is that it seems incompatible with the national and international understandings of the ne bis in idem rule. As mentioned above, Ecuador's Criminal Code forbids a second prosecution based on the "same facts." 122 The Spanish version of Article 8(4) of the American Convention on Human Rights also forbids a second prosecution for "los mismos hechos" (the same facts). The English version talks about the "same cause," but the Inter-American Court has stated that the ne bis in idem "is based on the prohibition of a new trial on the same facts that have

\footnotetext{
115 IACHR, Bueno Alves v. Argentina, 2007.

116 IACHR, Fernandez Ortega v. Mexico, 2010.

117 IACHR, Cabrera García and Montiel Flores v. México, 2010.

118 Constitution, supra n. 17, Art. 66(3).

119 For instance, Art. 5 of the American Convention on Human Rights and Article 7 of the International Covenant on Civil and Political Rights.

120 IACHR, Gómez Paquiyauri Brothers v. Peru, 2004.

121 Constitutional Court, Judgment No. 008-15-SCN-CG, Cases Nos. 0005-11-GN; 005811-GN; 0021-12-CN; and 0003-13-GN, 5 August 2015.

122 Criminal Code, Article 5 (9).
} 
Esta revista forma parte del acervo de la Biblioteca Jurídica Virtual del Instituto de Investigaciones Jurídicas de la UNAM

been the subject of the judgment under authority of res judicata."123 The relevance lies in the "same facts," and not in whether those facts produced different offences, or whether one jurisdiction has a different aim than the other one.

\section{Exceptions to the Ne Bis In Idem Rule}

The ne bis in idem rule, while important, is not absolute. According to the Inter-American Court, the rule is not applicable in two circumstances: 1) when the proceedings were not conducted independently and impartially in accordance with due procedural guarantees, and 2) when there was no real intention of bringing those responsible to justice, because the judicial investigation, the proceedings and the judicial decisions "were not truly intended to elucidate the facts, but rather to obtain an acquittal of the accused". ${ }^{124}$ Furthermore, the Inter-American Court has stated that States have the duty to avoid and fight against impunity. ${ }^{125}$ Impunity may arise in different manners: as a result of the State's failure to organize the mechanisms necessary to investigate a crime, ${ }^{126}$ or by carrying out domestic proceedings that result in delays and undue hindrances; ${ }^{127}$ or by failing to formally define crimes, which prevents the adequate performance of criminal proceedings; ${ }^{128}$ or by adopting self-amnesty laws; ${ }^{129}$ or by failing to enforce the imposed sentence; ${ }^{130}$ or by imposing upon those found guilty insignificant punishments that are fully inconsistent with the seriousness of the crime, ${ }^{131}$ among others.

The Inter-American Court's standards could have assisted the Constitutional Court in reaching a more solid decision. If Indigenous adjudicators were not impartial or independent, if the proceedings before them did not provide procedural guarantees, if there was no real intention to punish the crime, then there was an apparent res judicata, ${ }^{132}$ and the ne bis in idem rule

123 IACHR, Mohamed v. Argentina, 2012, para. 125. The Inter-American Court also acknowledged that Article 8(4) of the American Convention afforded a "much broader" protection to the defendant than other international treaties, such as Article 14(7) of the International Covenant on Civil a Political Rights that only forbids a second prosecution for the same "offence" (Id para. 121).

124 IACHR, Carpio Nicolle et al. v. Guatemala, 2004, para. 131; IACHR, Almonacid Arrelano et al. v. Chile, 2006, para 154; IACHR, Nadege Dorzema et al. v. Dominican Republic, 2012, para. 195.

125 IACHR, Tiu Tojín v. Guatemala, 2008, para. 69.

126 IACHR, Velásquez-Rodríguez v. Honduras, 1988, paras. 176-177.

127 IACHR, Bulacio v. Argentina, 2003, para. 115.

128 IACHR, Heliodoro-Portugal v. Panamá, 2008, para. 183.

129 IACHR, Barrios Altos v. Peru, 2001, para. 43.

130 IACHR, Valle-Faramillo et al. v. Colombia, 2008, para. 165.

131 IACHR, Vargas-Areco v. Paraguay, 2006, paras. 106-109.

132 IACHR, Nadege-Dorzema v. Domincan Republic, 2012, para. 196. 
would not be applicable. Similarly, had the Constitutional Court have considered that the crime was not formally defined in the Indigenous legal system; or if the decision was not enforced properly by the Indigenous adjudicators; or if the imposed punishments were not consistent with the seriousness of the crime, or did not provide results that are important in a democratic society (deterrence, prevention, retribution, rehabilitation, etc.), leading the case to linger in total or partial impunity, a re-trial could have been ordered. Sadly, the reasoning of the Constitutional Court did not touch upon any of these issues.

\section{Gonclusions}

Having different legal systems coexisting in the same place and at the same time creates a laboratory for forum shopping and shopping forums. The multiplicity of authorities, procedures and regulations fosters the possibility that some disputants can choose a system that offers the best probabilities of success. However, not all the disputants are in an equal position of choosing, and some do not even know that they have a choice. Power imbalances and inequalities within Indigenous communities play an important role in these choices.

Forum shopping can be a blessing or a curse. Depending on who is buying, it could be an unfair and utilitarian exploitation of the system, a way of taking advantage of legal loopholes in the coordination and cooperation between different systems, or a selfish manner by which to bypass of the consequences of wrongful acts. At the same time, it could improve access to justice for those who were traditionally the minority within the minority, less powerful subgroups, or vulnerable individuals. The focus should be on the "buyer" and his or her reasons to choose one forum over the other.

As to shopping forums, Ecuador's Constitution states that the administration of justice is a collective right of Indigenous peoples. Being a right, its right-holder (Indigenous communities) may decide to exercise it or not. When Indigenous adjudicators decide to administer justice or decide not to administer justice, they are in fact "shopping" the controversies.

Indigenous individuals have the right to be tried by a competent judge, that is to say, a natural judge, from their own system and culture. Consequently, the decision of Indigenous adjudicators to solve a case or not should be weighed against the right of individuals to access justice. Neither the collective right nor the individual right should be absolute. Good reasons should be given if one right is to be limited or restricted in favor of the other.

Ecuadorian law included the ne bis in idem rule as a way of limiting forum shopping and shopping forums. In theory, if a case has been decided by one legal system, the other system should refrain from hearing the same case again. However, according to the Constitutional Court, Indigenous justice deals with 
Esta revista forma parte del acervo de la Biblioteca Jurídica Virtual del Instituto de Investigaciones Jurídicas de la UNAM

the collective dimensions of the right to life, while ordinary justice deals with its individual dimension. Because of this, the Court found no violation of the ne bis in idem rule in a case where ordinary adjudicators heard a case already resolved by Indigenous adjudicators. The reasoning of the Court was flawed and it appears to contradict the purposes of the inclusion of the ne bis in idem rule. Finally, the rule is not absolute, and there are certain cases in which it is not applicable, mainly because the first trial demonstrated serious deficiencies or there was no real intention to bring the defendant to justice. In such cases, there is apparent res judicata and it is possible to order a second trial. The Constitutional Court did not explore the non-absolute nature of the rule, which demands a case-by-case analysis. Instead, it passed a general prohibition against Indigenous adjudicators hearing future cases related to the right to life. Whether the Court limited the jurisdiction of Indigenous adjudicators beyond what is possible or desirable in a legally pluralistic society is a topic that deserves further research. For the purposes of this article, the Court's decision fits awkwardly with the ne bis in idem rule. 